\title{
The formation of a criteria-based approach in the development of projects of redevelopment of industrial real estate
}

\author{
Vadim Kankhva, ${ }^{1, *}$, Boris Orlov $^{2}$, Alla Vorobyeva $^{2}$, Svetlana Belyaeva ${ }^{3}$ and Rima Petrosyan ${ }^{1}$ \\ ${ }^{1}$ Moscow State University of Civil Engineering, Yaroslavskoye shosse, 26, Moscow, 129337, Russia \\ ${ }^{2}$ Moscow state University of technology and management. K.G. Razumovsky (PKU), Moscow, \\ 109004, Russia \\ ${ }^{3}$ Voronezh State Technical University, Moscow Avenue, 14, Voronezh, 394026, Russia
}

\begin{abstract}
The purpose of this article is the development of management process of redevelopment of industrial real estate, based on the criteriabased approach for accepting the form of development. Developing the proposed approach was feasible due to the study of the efforts of foreign experts and experience of the redevelopment projects in Russia. In addition, the article presents the classification of redevelopment of nonresidential property, based on three main criteria's. The proposed algorithm extends the core taking into account the specifics of the three forms of development of objects of real estate (reconstruction, modernization and redevelopment) and is focused on the development of the industrial estate.
\end{abstract}

\section{Introduction}

Modern trends in technology, Economics, manufacturing, transport and communications lead to the necessity of city development. Urban areas with existing buildings and structures, enterprises, industrial districts, which were built ten and sometimes hundreds of years ago, is increasingly no longer meet modern standards and require additional investments to bring them into compliance with the new conditions of land using. The Russian real estate market is developing rapidly, especially in the largest cities there are clearly inefficiently used facilities and areas.(it is clear that facilities and territories are used inefficiently) Cities entered into the postindustrial era - because of that it is necessary to find new ways to improve their infrastructure, which are directly associated with the redevelopment process. Redevelopment, as a peculiar kind of business, associated with the complex transformation of real estate, meets the requirements of developing economy of Russia [1]. It's main purpose is to increase the cost of the facilities due to technical and organizational improvement, modern marketing research, qualitative forecasts of future product demand, market goods and services, and levels of potential risks.

\footnotetext{
* Corresponding author: vskanhva@mail.ru
} 
In order to simplify communication and relationship among the participants of the redevelopment project, this or that project should be identify. As the real estate, redevelopment can be classify by the scale of the project and the principle of functionality.

\section{Materials and methods}

In the course of study, the authors have simplified and summarized the existing classification of real estate redevelopment, picture 1. According to the classification of the redevelopment is divided into complex and individual.

Comprehensive redevelopment - redevelopment of existing territories, urban areas and large industrial complexes.

Point redevelopment - redevelopment of individual buildings and structures.

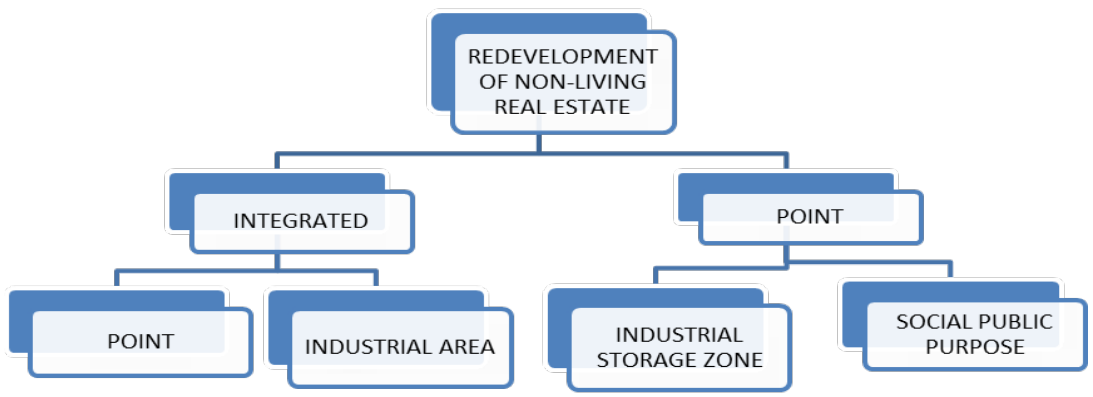

Fig. 1. Classification of redevelopment of non-living real estate.

The classifications of redevelopment is based on the three main criteria:

- physical ,associated with physical characteristics of object;

- legal ,associated with the legal aspects of object;

- economic , associated with the financial and economic aspects of object.

Based on these criterias, we can classify the redevelopment in details:

1. Size of projects: the value of usable area and payback period:

- global - require significant investments that are associated with the clearing of the territories occupied by former production facilities, construction of new facilities, relocation or closure of businesses and expenses sent to local and national budgets.

- local - associated with the transforming of existing buildings and structures into another purpose.

2. Due to the occurrence:

- competition - the emergence of new formats, network development;

- obsolescence - a discrepancy between current standards of comfort and safety;

- the lack of sufficient funding;

- changes of the demand and market saturation;

3. The depth of object changes:

- with the dismantling of the object;

- without objects dismantling;

4. Type of reconstruction:

- without taking the object out of service;

- with the taking object out of service;

5. The necessarily for alternative sites:

- with the transfer object;

- with removal object from service; 
6. The form of the ownership:

- state;

- municipal;

- private;

- mixed;

7. The number of owners of the object:

- one owner;

- collective ownership;

8. On the necessity of changing the permitted use (LIE) of the land plot:

- with the need to change the LIE of the land;

- without the need to change the LIE of the land;

9. Status of the object:

- which have got the status of a cultural heritage site;

- which haven't got the status of a cultural heritage site;

10. Functional purpose:

- upgrade without changing the functionality (for example, in the segment of office real estate: offices from class $\mathrm{C}$ to class B);

- professional shopping centers - retail parks;

- change of functional use: (residential buildings - hotels).

11. By source of investment:

- state budget;

- municipal authorities;

- large redevelopers company;

- private investors;

- reinvestment of current income from rent;

12. By type of investment:

- without borrowing costs;

- with borrowing costs;

13. The level of risk of the project:

- high-risk projects;

- projects with low risk.

The development of the project concept (restructuring) redevelopment - is difficult and interesting process at the same time. This follows from the fact that it connects two opposite principles: creativity and computation [2].

The necessity for methodological foundations for the project redevelopment due to the fact that the real estate segment, on the one hand, is an attractive investment, and with another - a highly expensive and dangerous.

Despite the apparent ease of determining the possible using of the territory, there are a number of limitations that should be considered in the initial stage of the redevelopment project. Restrictions can be physical, legal or social nature.

Now Russia, and also many other countries, have real problem of complex development of territories inside and outside the city.

Managing the development of the object, as a rule, begins with the definition of highest and best using of land. Determination based on the analysis of large amounts of information about relative place and relative environment. First, it is the deep analysis of potential locations from all areas: from physical and legal characteristics, and this analysis determines the allowed options for the development of territories. Secondly, one of the main factors that determine the most effective choice of development of the territory, is the situation with the market. This also includes the relationship of supply and demand in the 
different segments of the real estate market in the study area, competing facilities in various segments and evaluation in a certain segment and region.

Thereby, the development of the object of real estate which based on the redevelopment is an analytical justification for ideas that can be presented in the form of the algorithm. This algorithm will allow the owner, the investor and other involved parties to assess the interest and capacity to implement the project, and on this basis take the necessary decisions with the methodical approach to begin work on the implementation of the redevelopment project $[2,3]$.

\section{Results}

As a result of the researches reflected in this work it possible to highlight which areas should be fully and comprehensively estimated for revealing of property redevelopment:

- the study area in terms of economy, urbanism, landscape, ecology, etc.

- solidity and physical condition of the building;

- determining the current functional purpose of object of real estate (industrial, communal storage, degraded areas, carpool, etc.);

- the negative impact on the environment;

- analysis of cultural, historical, and architectural values of the area and buildings (monuments, ordinary building, unique and modern architecture);

- the determination of the form of ownership;

- profitability;

Further development of the object of real estate-based redevelopment involves performing the following actions:

1. Definition and selection of new functional using, taking into account of the architectural requirements, customer requirements, investment aspects and legal parameters, and then choosing forms of redevelopment of the property: renovation, modernization or conversion.

2. The calculation of the budget of the project in selected areas of implementation redevelopers real estate project (estimation of investments and costs in the implementation of the project, calculation of incomes and expenses of future object using).

3. Calculation of financial and economic performance indicators for each of the selected areas.

4. The definition of social-economic performance indicators of the project.

5. On this basis, draw up a matrix of subject characteristics (table 1) necessary for making decisions on the form of development of real estate objects of different functional purpose, where the $\mathrm{R}$ - reconstruction, $\mathrm{M}$ - upgrade, $\mathrm{P}-$ reconstruction, $\mathrm{P}+\mathrm{R}-$ reconstruction with the change of functionality.

To construct table view, select the required list initial minimum conditions of carrying out the redevelopment plan.

1. Regarding the conditions of the real estate market:

- the purpose of the building refers to the segment of the market that are in demand;

- the purpose of the building is obsolete from the point of view of efficiency and demand;

2. Regarding municipal development plans of the city:

- the future development of the district and needs in the provision of services to the intended use of the building;

- the future development of the district and needs in the provision of services does not meet the purpose of the building;

- the building has the status of a monument or it has historical and architectural value; 
- common buildings;

3. Subjective conditions of building status:

- concurrence with state control and regulation on changing the functional purpose of the building;

- lack of concurrence with state control and regulation on changing the functional purpose of the building;

- availability of necessary communications and engineering loads;

- possibility of the parking;

- lack of the possibility of the parking;

- building refers to the 1-3 class of solidity;

4. Functional conditions which are defined by the goals of the redevelopment:

- the necessity to increase the construction volume of the building;

- the building is planned in the existing dimensions;

- increasing the level of engineering equipment;

Table 1. Criteria for deciding on the form of development of non-residential real estate-improvement of architectural expressiveness of building.

\begin{tabular}{|l|c|c|c|c|}
\hline \multicolumn{1}{|c|}{ Object characteristic } & $\begin{array}{l}\text { high moral } \\
\text { wear and } \\
\text { satisfactory } \\
\text { technical } \\
\text { condition }\end{array}$ & $\begin{array}{l}\text { high moral wear } \\
\text { and } \\
\text { unsatisfactory } \\
\text { technical } \\
\text { condition }\end{array}$ & $\begin{array}{l}\text { satisfactory } \\
\text { moral and } \\
\text { technical } \\
\text { condition }\end{array}$ & $\begin{array}{l}\text { satisfactory } \\
\text { moral and } \\
\text { unsatisfactory } \\
\text { technical } \\
\text { condition }\end{array}$ \\
\hline $\begin{array}{l}\text { The designation of a } \\
\text { building refers to a market } \\
\text { segment that is in demand }\end{array}$ & $\mathrm{M}$ & $\mathrm{R}$ & $\mathrm{M}$ & $\mathrm{R}$ \\
\hline $\begin{array}{l}\text { The purpose of the building } \\
\text { is outdated in terms of } \\
\text { efficiency and demand the }\end{array}$ & $\mathrm{P}$ & $\mathrm{P}+\mathrm{R}$ & $\mathrm{P}$ & $\mathrm{R}$ \\
\hline $\begin{array}{l}\text { The prospect of the } \\
\text { development of the district } \\
\text { and the needs for the } \\
\text { provision of services } \\
\text { corresponds to the purpose } \\
\text { of the building }\end{array}$ & $\mathrm{M}$ & $\mathrm{P}$ & $\mathrm{M}$ & \\
\hline $\begin{array}{l}\text { The prospect of the } \\
\text { development of the district } \\
\text { and the needs for the } \\
\text { provision of services does } \\
\text { not correspond to the } \\
\text { purpose of the building }\end{array}$ & $\mathrm{P}$ & $\mathrm{P}+\mathrm{R}$ & $\mathrm{P}$ & $\mathrm{P}+\mathrm{R}$ \\
\hline $\begin{array}{l}\text { The building is given the } \\
\text { status of a monument or it } \\
\text { has a historical and } \\
\text { architectural value }\end{array}$ & $\mathrm{M}$ & $\mathrm{R}$ & $\mathrm{M}$ & $\mathrm{R}$ \\
\hline $\begin{array}{l}\text { Block building } \\
\text { Appointment } \\
\text { coordination with the state } \\
\text { control and regulation } \\
\text { bodies on the change of the } \\
\text { functional purpose of the } \\
\text { building }\end{array}$ & $\mathrm{P}$ & $\mathrm{P}+\mathrm{R}$ & $\mathrm{P}$ & \\
\hline possibility of parking & $\mathrm{M}$ & $\mathrm{R}$ & $\mathrm{R}$ \\
\hline $\begin{array}{l}\text { the lack of parking in the } \\
\text { existing conditions }\end{array}$ & $\mathrm{R}$ & & $\mathrm{R}$ & \\
\hline
\end{tabular}




\begin{tabular}{|l|c|c|c|c|}
\hline $\begin{array}{l}\text { the building belongs to the } \\
\text { 1-3 class of capital }\end{array}$ & $\mathrm{M}$ & $\mathrm{R}$ & $\mathrm{M}$ & $\mathrm{R}$ \\
\hline $\begin{array}{l}\text { need to increase the } \\
\text { building volume of the } \\
\text { building }\end{array}$ & $\mathrm{R}$ & $\mathrm{R}$ & $\mathrm{R}$ & $\mathrm{R}$ \\
\hline $\begin{array}{l}\text { the building is planned in } \\
\text { the existing dimensions }\end{array}$ & $\mathrm{M}$ & $\mathrm{M}$ & $\mathrm{M}$ & $\mathrm{M}$ \\
\hline $\begin{array}{l}\text { increasing the level of } \\
\text { engineering equipment }\end{array}$ & $\mathrm{M}$ & $\mathrm{R}$ & $\mathrm{M}$ & $\mathrm{R}$ \\
\hline $\begin{array}{l}\text { improvement of the } \\
\text { architectural expressiveness } \\
\text { of the building }\end{array}$ & $\mathrm{R}$ & $\mathrm{R}$ & $\mathrm{R}$ & $\mathrm{R}$ \\
\hline
\end{tabular}

The key to success of any investment project of real estate is the pre-professional analysis. Analysis of the best and most efficient use of the property is the starting point of implementation of all project in the real estate market. Analysis of the best use of the available space will allow redeveloper to make decision about the format of the future project [4].

In the study there were analyzed house,market, office, hotel and interesting adjacent to the object the perception and image of the future building area from the point of view of potential buyers, renters and visitors.

It is proposed to perform an analysis of the opportunities and limitations of the property, understanding the situation in the developed market of real estate to push several promising hypotheses of the possible use in terms of implementation for the further analyze the highest and best use in the redevelopment project.

Within the test each of the hypotheses of the best use to be performed, the analysis of each showed strengths and weaknesses that become conclusions about the appropriateness of the choice of this or that hypothesis. Then, a preliminary assessment of necessary investment volumes and efficiency of the project depending on every selected hypotheses should be asses $[5,6]$.

The concept of most type in the future commercial use of the object, which guarantees redeveloper the highest profit from the most efficient use of the property will be a result of work on the analysis of best use.

Analysis of the market for professional services in the field of real estate, including real estate appraisal, market research of the real estate, shows that wrong decisions redeveloper according to the future building project can lead to large-scale financial and time losses.

Following this, we can see a practical algorithm of the development of the property based on the proposed methodological approach developed for decision on the form and economic feasibility of object development (figure 2). The algorithm clearly shows the phasing of implementation of development projects of real estate objects, their complexity, dependence on factors external and internal environment and reflects the process of making managerial decisions on the development of the object $[7,8]$. 


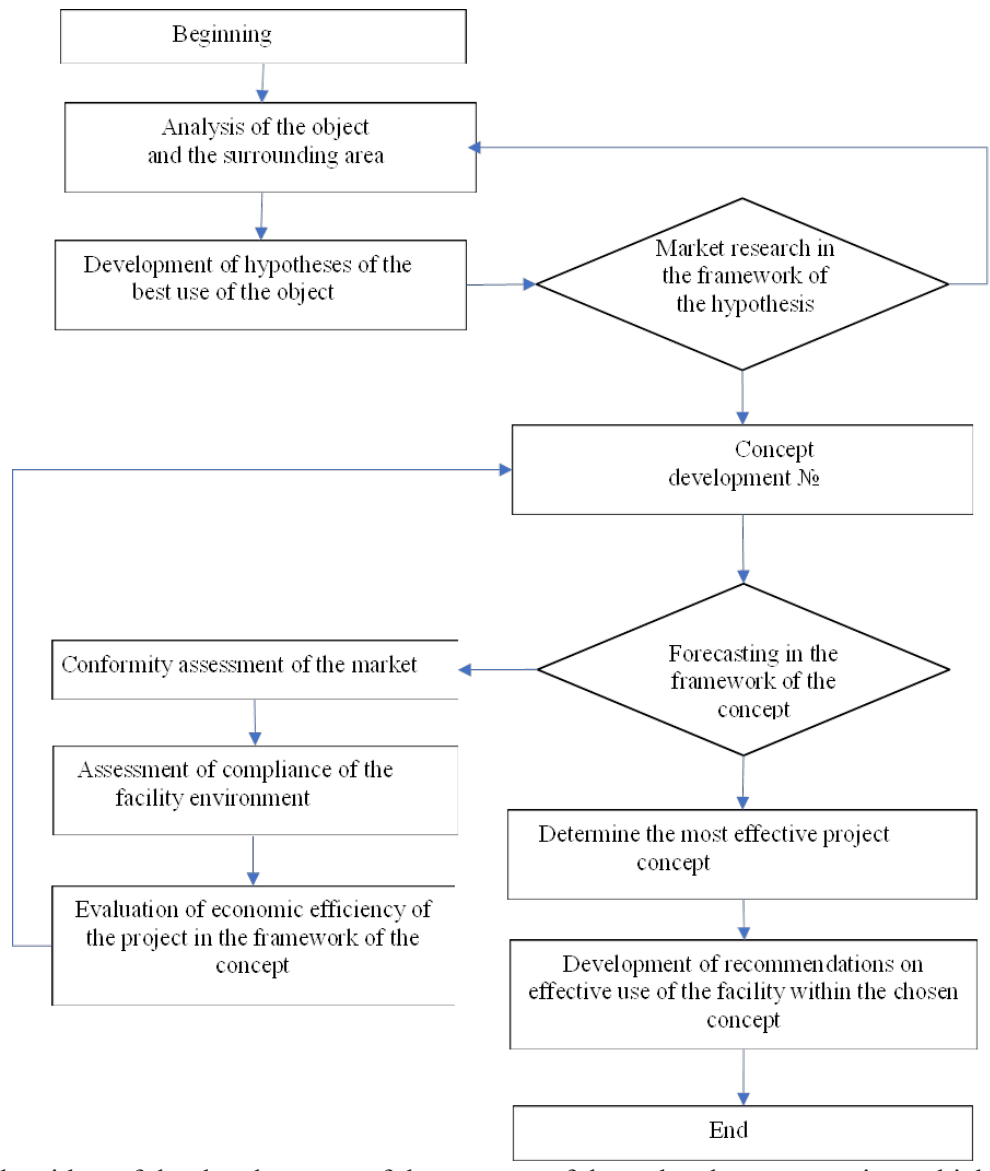

Fig. 2. The algorithm of the development of the consent of the redevelopment project which is based on the proposed methodological approach.

\section{Discussions}

Despite the large number of different publications on economic and organizational issues of investment and construction activities on real estate development and implementation of redevelopers projects for the development of non-residential real estate lit is very limited among the participants in the redevelopment process there is not union understanding of the stages, objectives, tasks, process, evaluation methods of projects redevelopment efficiency.

\section{Conclusion}

In the research, which is biased on the criterial approach when the deciding on the form of development of real estate, developed a practical control algorithm of the development of non-residential real estate and made the choice of the most effective directions of object using, taking into account economic and social indicators.

The algorithm will allow to the owner, investor and other parties to assess the interest and possibilities for the implementation of the project, and on this basis make the necessary decisions with the help of a methodological approach to begin work on the implementation of the redevelopment project. 


\section{References}

1. D.N. Silka, World Applied Sciences Journal 31, 148-150 (2014)

2. A.V. Talonov, Property management (Yurayt, Moscow, 2014)

3. F. Aggogeri, A. Borboni, R. Faglia, Applied Mechanics and Materials (2013) DOI: 10.4028/www.scientific.net/AMM.373-375.130

4. R. Brazauskas, J. Le-Rademacher, Computer Methods and Programs in Biomedicine 135, 199-207 (2016)

5. V. Pukhkal, V. Murgul, M. Garifullin, Procedia Engineering 117, 624-627 (2015)

6. I. Kardes, A. Ozturk, S.T. Cavusgil, E. Cavusgil, International Business Review 22, 905-917 (2013)

7. E.K. Chirkunova, E.E. Kireeva, A.D. Kornilova, J.S. Pschenichnikova, Procedia Engineering 153, 112-117 (2016)

8. B. Hirtle, A. Kovner, J. Vickery, M. Bhanot. Journal of Banking \& Finance 69(1), 3555 (2016) 